\title{
A BETTER WAY TO STRENGTHEN THE QUADRICEPS MUSCLE IN GRADE III PATIENTS AFTER ACL INJURIES TO REDUCE THE RECOVERY PERIOD
}

\author{
V.L. Lim \\ Nanyang Technological University, \\ Singapore
}

\begin{abstract}
The project proposes a way to strengthen the quadriceps muscle in active patients during pre and post surgery of anterior cruciate ligaments injury to reduce the recovery period. Anterior Cruciate Ligament (ACL) injury is the most common knee injury. Treatment for ACL tear varies depending on the severity and patient's activity level, but typically involves rehabilitation or surgery. Patients undergoing surgery would need six to nine months to return to sports or other activities with the current rehabilitation program post-surgery, with adherence to physiotherapy playing a crucial role. Based on our research, we propose to develop a smart knee sleeve product. This smart product is composed of fully integrated sensors with breathable skin material. First component of sensor is to detect and measure the range of motion; second is to sense the muscle strength; third is to simulate quadriceps muscle and fourth is to relieve chronic pain associated with the injury. All the functions of device can be controlled via an app and data is saved at cloud system. Integrating smart sensors together with functionalities which enable monitoring and tracking of data at real time will greatly increase the patient's compliance level while speeding recovery. Most importantly, recovery period can be shortened by $50 \%$.
\end{abstract}

\section{INTRODUCTION}

\section{DISEASE STATE}

Anterior Cruciate Ligament (ACL) is a part of cruciate ligaments of each knee, attaches the front of the tibia with the back of the femur. It is an important internal stabilizer for the knee joint.

An Anterior Cruciate Ligament tear is a relatively sporting injury affecting the knee and is characterized by tearing of the ligament, which makes the knee less stable. The 70 percent of ACL tears are non-contact injuries occurring primarily during deceleration of the lower extremity, with the quadriceps maximally contracted and the knee at or near full extension. ACL injuries were graded based on the severity into three grades. The most common injuries are severe Grade III (more than 50\%). (P. Colombet, 2010)

Injury to the Anterior Cruciate Ligament (ACL) is one of the most devastating and frequent injuries of the knee. In the United States, there are about 200,000 ACL ruptures annually, with the incidence of approximately 1 in 3000. (Anon., n.d.) Athletes who participate in high demand sports like soccer, football, and basketball are more likely to injure their ACL.

\section{TREATMENT OPTIONS}

Treatment for ACL tear such as rehabilitation or surgery will vary depending on the severity and patient's activity level. Patients undergoing surgery would need six to nine months to return to sports or other activities with the current rehabilitation program post-surgery, with adherence to physiotherapy playing a crucial role.

As the quadriceps strength is the gold standard indicator of how well the patient will perform after an ACL injury;(Manske, 2012)the recovery time ties closely with the effectiveness of quadriceps strengthening. However, currently insurance companies in the US do not pay for as many direct physical therapy visits which limits the patients' participation in the recovery program, thus largely affecting the effectiveness of the quadriceps strengthening. Additionally, patient compliance presents another challenge in the rehabilitation program. As it is important for the injured patient to understand the significance of each step to avoid complications and ensure an effective recovery.

The device to strengthen the quadriceps muscle in the market is called Neuromuscular electrical stimulation (NMES) device, which is a therapy defined by the elicitation of muscular contractions utilizing electrical impulses. As illustrated in the below graph, there is a potential treatment gap between physical therapy with therapist and current NMES device available in terms of the efficacy of quadriceps strengthening as well as the cost of treatment. 


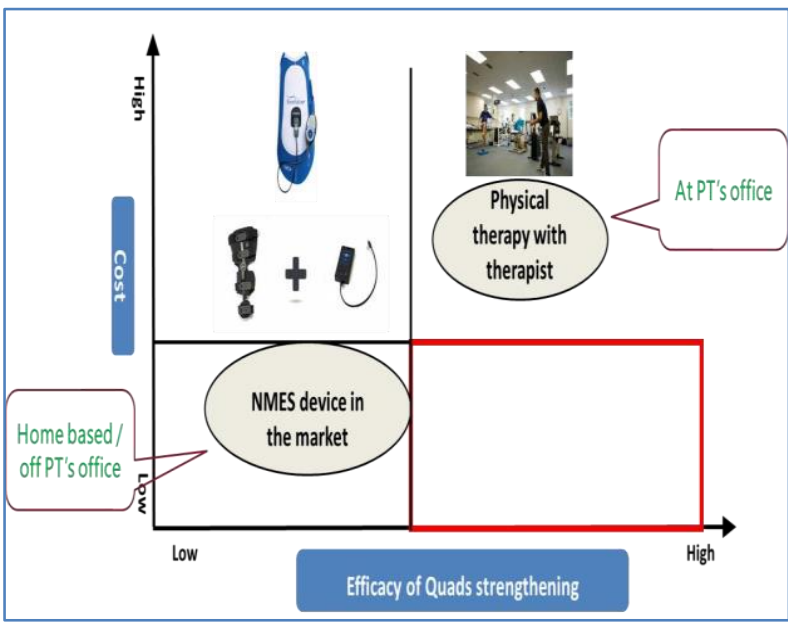

Figure 1: Treatment Gap in ACL post-surgery Rehab

\section{MARKET ANALYSIS}

The Anterior Cruciate Ligament is cited as the most frequently injured ligament in the knee. ACL injury has an annual incidence of more than 200,000 cases in US. More than half of them (over 100,000) are treated by ACL reconstruction surgery. The total number of ACL reconstructions increased from 86.837 cases in 1994 to 134.421 cases in 2006, as reported by Leonard T. buller (2015). And ACL/PCL reconstruction is the largest practiced procedure in the orthopaedic soft tissue repair market and it is expected to grow at a CAGR of about 8.3\% during 2013 - 2019(Reportlinker, 2013-2019).

Anon (n.d.) noted that ACL injury is most prevalent (1 in 1,750 persons) in patients $15-45$ years of age.It is more common in this age group in part because of their more active lifestyle as well as higher participation in sports.

The average cost for physical therapy treatment of postsurgery ACL injury is around $\$ 10,000$ which makes the rehab treatment market size about $\$ 1$ billion, as noted by Timothy E. Hewett (2010).

A potential device should be able to win a fraction of the existing ACL rehab treatment market especially it is able to promise a shorter recovery time.

\section{STAKEHOLDER ANALYSIS}

As tabulated below, Patients and physical therapist are likely incentivized to adopt the change.

\begin{tabular}{|c|c|c|c|c|}
\hline Stakeholder & $\begin{array}{c}\text { Primary } \\
\text { Interests }\end{array}$ & $\begin{array}{c}\text { Primary } \\
\text { Cost }\end{array}$ & $\begin{array}{c}\text { Overall } \\
\text { Incentive }\end{array}$ & $\begin{array}{c}\text { Key } \\
\text { Decision } \\
\text { Maker }\end{array}$ \\
\hline
\end{tabular}

\begin{tabular}{|c|c|c|c|c|}
\hline Patients & $\begin{array}{c}\text { Effective } \\
\text { treatment } \\
\text { Comfortable } \\
\text { Lower cost }\end{array}$ & $\begin{array}{c}\text { Lack of } \\
\text { professional } \\
\text { advice }\end{array}$ & Positive & Yes \\
\hline $\begin{array}{c}\text { Physical } \\
\text { Therapists }\end{array}$ & $\begin{array}{c}\text { Able to treat } \\
\text { more patients } \\
\text { still be involved in } \\
\text { the innovation }\end{array}$ & $\begin{array}{c}\text { Need learn } \\
\text { the new procedure }\end{array}$ & Positive & Yes \\
\hline Orthopaedic & $\begin{array}{c}\text { None, } \\
\text { assuming no } \\
\text { impact on current } \\
\text { surgical procedures }\end{array}$ & None & Positive & No \\
\hline surgeon & $\begin{array}{c}\text { Innovation } \\
\text { lowers the cost per } \\
\text { patient }\end{array}$ & $\begin{array}{c}\text { None if cap } \\
\text { Payer max. claimable } \\
\text { amount }\end{array}$ & Positive & Yes \\
\hline \multicolumn{2}{|l|}{} & & \\
\hline \multicolumn{2}{|l|}{} & & \\
\hline
\end{tabular}

\section{NEED STATEMENT}

Based on the above analysis, we believe there is a need for " $A$ Cost-Effective Way To Strengthen the Quadriceps Muscle In Patients With Complete ACL Tear (Grade III) To Reduce The Recovery Time ".

\section{NEEDS CRITERIA}

\begin{tabular}{|c|l|}
\hline Must Have & Nice to Have \\
\hline$\underline{\text { Safe for the patients }}$ & $\begin{array}{l}\text { Integrate to the } \\
\text { existing procedure }\end{array}$ \\
\hline $\begin{array}{l}\text { Quadriceps strength deficit down } \\
\text { from 20\% to 10\% at 6 months post- } \\
\text { ACL reconstruction(Palmieri-Smith, } \\
2008)\end{array}$ & $\begin{array}{l}\text { Comfortable and } \\
\text { user-friendly for the } \\
\text { patients }\end{array}$ \\
\hline $\begin{array}{l}\text { Reduce the recovery time by } \\
50 \% \text {, i.e. 3 months }\end{array}$ & $\begin{array}{l}\text { Easy to use or } \\
\text { learn for average } \\
\text { physio therapists to } \\
\text { facilitate rapid } \\
\text { adoption }\end{array}$ \\
\hline $\begin{array}{l}\text { Comparative cost with the } \\
\text { current techniques: } \frac{\text { cos }}{<800}\end{array}$ & \\
\hline
\end{tabular}

\section{EXPERIMENT AND RESULT}

\section{DESCRIPTION OF SOLUTION}

As our focus is to reduce recovery period for active patients after post ACL reconstruction, we proposed to develop a smart knee sleeve product which is made of breathable silicone material. This smart product is composed of fully integrated flexible sensors inside the sleeve which is intact contact like 


\section{International Journal of Engineering Applied Sciences and Technology, 2020 \\ Vol. 4, Issue 9, ISSN No. 2455-2143, Pages 14-25 \\ Published Online January 2020 in IJEAST (http://www.ijeast.com)}

skin and very light weight while maintaining a cost-effective factor. First components of sensor is to detect and measure the range of motion, second is to sense the muscle strength, third is to simulate quadriceps muscle and fourth is to relieve chronic pain in the body. The device with integrated smart sensors is to reduce the patients rehab training period shorter and to gain faster recovery period, and give patients accurate and consistent result of muscle strengthening. All the functions of device can be controlled via same apps and data is saved at cloud storage system. Smart sensors together with ability to monitor and track data at real time will greatly increase the patient's compliance level while speeding up recovery period, most importantly; can be shorten by $50 \%$.

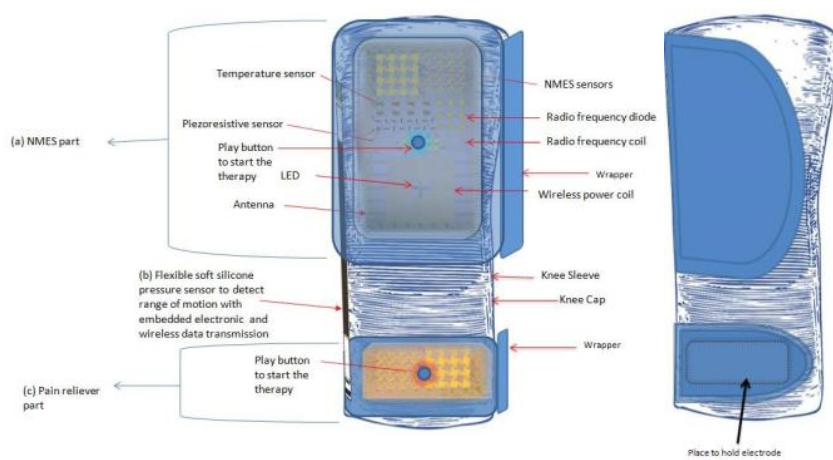

Figure 2: Details features of front and back smart knee sleeves design

(1) To solve inability to complete the whole 18 sessions of rehabilitation period after ACL reconstruction

A number of research and survey showed that most patients couldn't able to complete the whole 18 sessions. Here are a few reasons for noncompliance. Some patients feel that they can do the rehab exercises at home without going to physiotherapist and some may have issues such as healthcare cost, not convenient to travel, insurance coverage or other matters. However, rehab training to train quadriceps muscle cannot be achieved without monitoring and supervision to analyze the correct ways of doing rehab; therefore, it may deviate from proper compliance (Kirsten Jack, 2010 Jun)(Karnad P, 2011 Nov 16)(Fucai Han, 2015 December).

To overcome those known issues is to have a useful device or technology that can assist them to collect the data of their activities or exercises at home while it has ability to save data at cloud system via apps for their professional trainer (e.g. Physiotherapist) to monitor their techniques such as number of steps, joint angle measurement and acceleration after the activities. Ben O'Brien (2012-2016) and Matt Ball (2016) noted that bendable and stretchable sensors are a type of sensor which can be made in various sizes, elasticity and sensitivities depending on the different application. Those sensors are designed to measure soft structures like soft robots and the human body that can measure either stretch, bend, shear, or pressure.

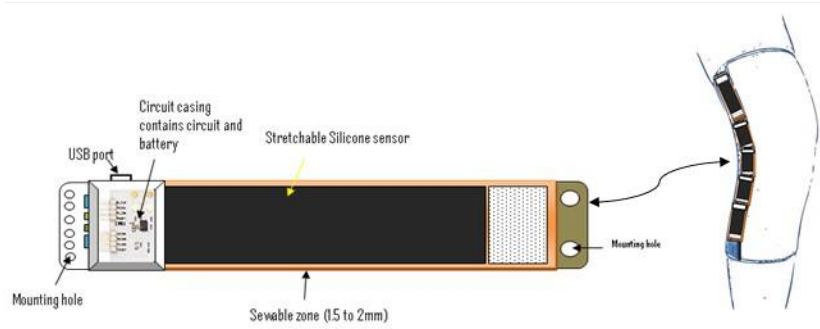

Figure 3: (Left) Design of silicone stretchable sensing sensor including micro PCB board and USB port (Right) silicone stretchable sensing sensor attached on knee sleeve

To measure range of the motion, the soft silicone stretchable sensors are embedded at both sides of knee sleeves in combination with custom electronics and algorithms for detecting movement data and to communicate smart phone app. The stretchable sensors can be attached inside knee sleeves by sewing along the length of the muscles (Figure.3) as pre-tensioned position to be able to move the stretch sensors along with the muscles as they contract. So, the strain sensors provide feedback on the current orientation of the join whenever the knee sleeve is actuated. The mechanism of the stretchable sensor is when the sensors deforms due to stretching or squeezing, its capacitance value change and the data of it capacitances is able to send to a Bluetooth enabled device to translate the detecting data of sensors via apps as suggested by A.Veale (n.d.) For example, system measures the range of motion to observe the performances of rehabilitation and exercises such as running, jogging, walking, cycling, hiking etc., in real time. The system will also allow having access via app for monitoring the range of motion and saving the data at cloud storage (e.g. Dropbox). This will be convenient for physiotherapist to check patients' activities and compliance level via cloud system while patients can visit any rehab training centre to continue their exercise sessions. 


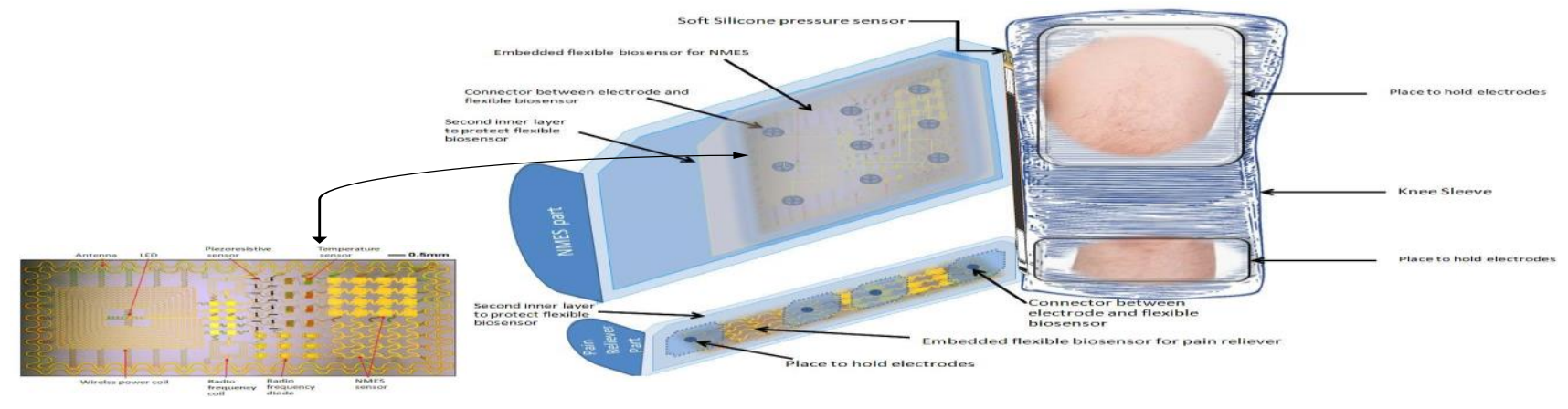

Figure 4: Detail features of NMES biosensors and electronic embedded inside the smart knee sleeve

(2) To solve failure to strengthen the muscles around the knee before and after ACL reconstruction

Muscles play a very important role in knee stabilization as they respond to the amount of stress placed on them. Muscles weaken and atrophy occurs when amount of stress on them decrease due to immobilization, protection and non-weight bearing. (Springs), 2012 May), Therefore, Palmieri-Smith (2008) and Eriksson E (1979) noted that many patients return to sport with lingering neuromuscular deficits and often have symptoms associated with the premature development of osteoarthritis although physicians and physiotherapist put their best efforts for recovery.

Persistent quadriceps weakness after knee injury is frequently reported in the literature and major challenge in rehabilitation for patients and clinicians. Quadriceps strength and endurance are very important for normal knee joint function; therefore, restoring normal quadriceps function after knee joint injuries is an essential component of rehabilitation. Insufficient training on muscles in pre surgery will also lead to muscle dystrophy and the muscles are hard to train after the surgery due to having the muscles weakness and large amount of pain as well. (Riann M. Palmieri-Smith, 2008)(Elmqvist LG, 1988)(Lorentzon R, 1989) This can prolong the rehabilitation period from 6 months to 12 months and in some cases, even longer.

There is strong evidence to suggest that arthrogenic muscle inhibition (AMI) and muscle atrophy are primarily responsible for the decrements in quadriceps strength. Therefore, the source of quadriceps muscle weakness must be considered when designing rehabilitation protocols. The best strategy is to minimize arthrogenic muscle inhibition (AMI) in pre and post surgery together with innovative technologies to reduce muscle atrophy. (Palmieri-Smith, 2008) Many researches had proved that NMES combined with voluntary exercises is more effective than voluntary exercise alone in restoring quadriceps strength during recovery period. (Anthony Delitto, 1988 May)
(SnyderMackler L, 1994 Oct)(Eriksson E, 1979)(Fitzgerald GK, 2003)(Wigerstad-Lossing I, 1988) Neuromuscular electrical stimulation (NMES) is a promising intervention to use after ACL reconstruction, while targeting to minimize AMI is the one of the rehabilitation goals. Therefore, our keen sleeve is designed to have combination of NMES and physiotherapy to have better strengthen the muscle and to speed up the recovery period. This smart knee sleeve has six placeholders to use with electrodes for NMES purpose and temperature sensor embedded inside flexible material sheet such PDMS or silicone. Each module has a connector to be used for connecting with electrodes. NMES is a non-invasive which applies customized electrical stimulus to cause different muscle fibre to contract. The principle of electrical stimulation is to stimulate nerve fibres to excite them by transmitting electrical impulses through electrodes and caused voluntary contraction.(Figure.2) Muscular twitch is caused by the excitation transmitted to the muscular fibers. However, the muscular response is controlled by the brain and the muscle cannot distinguish whether the command comes from the brain or from the stimulator. Different type of muscle fibers works differently according to their respective contraction speed such as slow, intermediate and fast fibers.

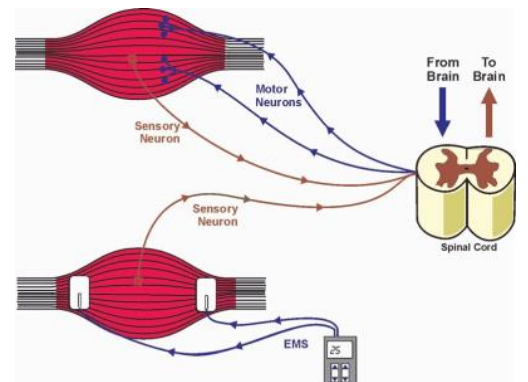

Figure 5: How electrical muscle stimulation contract muscles forcefully by using electrical impulses (Derek M. Hansen, n.d.) 


\section{International Journal of Engineering Applied Sciences and Technology, 2020 \\ Vol. 4, Issue 9, ISSN No. 2455-2143, Pages 14-25 \\ Published Online January 2020 in IJEAST (http://www.ijeast.com)}

Therefore, the flexible piezo-resistive silicone pressure sensor is included in our design to measure the quadriceps muscle force to evaluate reproducibility, linearity and stability. Base on the data generated from pressure sensor, the patients can set training objectives, level of intensity and choice of electrode pad location via apps and able to save the data at cloud system wirelessly. Moreover, electrical stimulation of the quadriceps muscle supports reduction of the atrophy as well. Patients can use NMES to stimulate the quadriceps muscle not only during rehabilitation training but also during and other times such as resting, sleeping and reading etc, and it will greatly boost frequency of muscle strengthening usage.

\section{3) To relieve pain while doing exercise}

The knee will usually be swollen, painful, weaken and has limited movement after ACL injury. Patient needs to go through pre-surgery rehabilitation training for the following reasons.

- To regain the strength and movement in the knee

- To improve balance

- To return range of motion to normal

- To minimize risk of post-operative stiffness

This training is to prepare ACL reconstruction surgery as well as to shorten the recovery period. However, pain will hinder in exercising, sleeping and daily activities that can affect the body strength and confident level. Pain can also affect the compliance level during rehabilitation period. Our product can be used both in pre and post ACL surgery. Our product includes the electrical pain reliever to relieve the pain by stimulating the sensory nerves which carry neural pulses to the brain. Pain reliever works very simple and it is user friendly. It works wirelessly and location is fixed on the knee sleeves in the upper calf of the knee. (Figure 4) Neural pulses trigger a natural response that blocks pain signals in anywhere of the body.

It can also automatically adjust the intensity level to receive optimal pain relief without patient's input. Target duration for pain relief of one session is minimum 60 minutes. This is helpful for the patients during rehabilitation training because they can complete their length of training without going through any pain during exercise and it will greatly enhance their range of motion when they do the exercise in certain position.

\section{TECHNICAL RISK AND CHALLENGES}

We are integrating three technologies to become one in our product. Since technical knowledge can be gain through the pioneer work, the technical risk for our product can be identified as low to median risk. Our goal is to make the light weight product and all the functions in our products should be user friendly and easy to learn. Frequently asked technical questions and other relevant questions will be available at online or user guide booklet.

\section{COMPETITION ANALYSIS}

Three key competitors identified are Kneehab $\mathrm{XP}^{\circledR}$, Cymedica QB1 and Empi Phoenix ${ }^{\mathrm{TM}}$.

\section{$\underline{\text { Kneehab XP }}^{\circledR}$}

Kneehab XP offers both NMES for quadriceps strengthening and improved knee stability, and TENS for pain management. Kneehab XP may be integrated into post-surgical treatment protocols to promote early quadriceps strengthening and knee stability as compared to using volitional exercises while addressing pain.(Neurotech, 2015)

Kneehab XP featuring Multipath ${ }^{\mathrm{TM}}$ technology simulates natural muscle recruitment sequence: Kneehab XP incorporates Multipath, a patented breakthrough stimulation technology that delivers highly focused, accurately coordinated quadriceps contractions. Multipath delivers multidirectional currents designed to recruit maximum muscle fiber and trigger stronger muscle contractions resulting in earlier post-surgical outcomes. Using this approach, Feil et al. showed better strength and functional scores in a group of ACL patients who supplemented their standard of care program with this multi-directional stimulation delivery system.(Neurotech, 2015)

A prospective, randomized, single blind study* carried out by the ATOS Clinic Center, Heidelberg, Germany, proves the treatment effectiveness of Kneehab XP in patients following anterior cruciate ligament reconstruction. Objective test measures showed Kneehab subjects regained pre-operative strength levels 3 months ahead of other study groups. Kneehab subjects also eclipsed non-operative leg strength measures within 12 weeks, a milestone never realized by the other groups. Overall, Kneehab subjects could return to work a full week earlier than the other groups.(Feil S, 2011 June)

\section{Cymedica QB1}

At the core of the QB1 system is the first and only closed-loop feedback system, which enables the device to simultaneously monitor and adjust the activation pulses delivered to the rectus femoris andvastus medialis muscles of the quadriceps based on the unique dynamic impedance and power dissipation properties of each patient. This allows the device to deliver high-intensity muscle activation more consistently and comfortably for the patient, often at a lower power, thereby improving patient satisfaction and compliance. For the ACL patient, the system adds a postoperative knee brace to protect, support and stabilize the knee, while also restricting the patient's range of motion. Collectively, these features aim to improve patient compliance, reduce quadriceps atrophy, and shorten rehabilitation.(Orthopedics, n.d.) 


\section{Empi phoenix $^{\mathrm{TM}}$}

The Empi Phoenix multifunctional electrical stimulation device is designed to simplify rehabilitation for all aspects of the recovery cycle. It consists of four pre-set electrotherapy program. Two programs are available for the management of muscle atrophy using neuromuscular electrical stimulation (NMES). Scientific studies have shown that the use of NMES after surgery provides statistically meaningful improvements in certain measures of strength and function. The third program utilises transcutaneous electrical nerve stimulation (TENS) for pain relief whereas the fourth programme delivers pulsed net direct current electrotherapy to increase circulation in a targeted area, thereby reducing swelling. (Global, 2016)

\section{VALUE PROPOSITION}

\begin{tabular}{|l|l|l|l|l|}
\hline & $\begin{array}{l}\text { TM } \\
\text { Empi } \\
\text { Phoenix }\end{array}$ & $\begin{array}{l}\text { Kneehab } \\
\text { XP® }\end{array}$ & $\begin{array}{l}\text { Cymedica } \\
\text { QB1 }\end{array}$ & $\begin{array}{l}\text { Our } \\
\text { Device }\end{array}$ \\
\hline Pain relief & $\square$ & $\square$ & $\mathrm{X}$ & $\square$ \\
\hline $\begin{array}{l}\text { Quad } \\
\text { muscle } \\
\text { activation }\end{array}$ & $\square$ & $\square$ & $\square$ & $\square$ \\
\hline $\begin{array}{l}\text { Monitoring } \\
\text { range of } \\
\text { motion }\end{array}$ & $\mathrm{X}$ & $\mathrm{X}$ & $\mathrm{X}$ & $\square$ \\
\hline $\begin{array}{l}\text { Monitoring } \\
\text { compliance }\end{array}$ & $\mathrm{X}$ & $\mathrm{X}$ & $\mathrm{X}$ & $\square$ \\
\hline $\begin{array}{l}\text { Patient } \\
\text { Experience }\end{array}$ & $\mathrm{X}$ & $\mathrm{X}$ & $\mathrm{X}$ & $\square$ \\
\hline
\end{tabular}

INTELLECTUAL PROPERTY LANDSCAPE

A summary of the intellectual property landscape is shown as below:

\begin{tabular}{|c|c|c|c|}
\hline Ref & Title & Patent & Date Filed \\
\hline 1 & $\begin{array}{l}\text { System and methods } \\
\text { for treating or } \\
\text { supporting human } \\
\text { joints or a portion of } \\
\text { the human } \\
\text { body(Struan } \\
\text { Coleman, 2014) }\end{array}$ & US 9072898 B2 & $\begin{array}{l}\text { Mar 14, } \\
2014\end{array}$ \\
\hline 2 & $\begin{array}{l}\text { Systems and } \\
\text { methods for treating } \\
\text { human joints (Struan } \\
\text { Coleman, 2014) }\end{array}$ & US 8870798 B2 & 9 Sep 2013 \\
\hline
\end{tabular}

\begin{tabular}{|c|c|c|c|}
\hline 3 & $\begin{array}{lr}\text { Method } & \text { and } \\
\text { apparatus } & \text { for } \\
\text { electrical } & \end{array}$ & US 6944503 B2 & 12 Jul 2002 \\
\hline & $\begin{array}{l}\text { Stimulation (Louis } \\
\text { Michael Crowe, } \\
\text { 2005) }\end{array}$ & & \\
\hline 4 & $\begin{array}{l}\text { Exercise device for } \\
\text { use with electrical } \\
\text { stimulation and } \\
\text { related methods } \\
\text { (Eric C. Hartman, } \\
2015 \text { ) }\end{array}$ & US9114255 & $\begin{array}{ll}18 & \text { Jun } \\
2012 & \end{array}$ \\
\hline 5 & $\begin{array}{l}\text { Apparatus and } \\
\text { method for range of } \\
\text { motion tracking with } \\
\text { integrated } \\
\text { reporting(Theoderick } \\
\text { Tam, 2016) }\end{array}$ & US20160220175A1 & $\begin{array}{ll}02 & \text { Feb } \\
2016 & \end{array}$ \\
\hline
\end{tabular}

Do I have freedom to operate?

Use of NMES and TENS are well-established. Overcome freedom to operate by developing specific configuration of how NMES and TENS can be incorporated to demonstrate synergy. Potential areas to explore include the output regulation, number of electrodes, electrode size, waveform and shape.

Is my technology patentable?

Current products only offer functional benefits such as pain relief, quad muscle activation. Our products go beyond the provisional of functional benefits and the novelty lies in developing an engaging and motivating patient experience to improve compliance. Features will also enable patient to monitor whether he is able performing physiotherapy appropriately and allows the physiotherapist to keep track of the adherence to treatment program 


\begin{tabular}{|c|c|c|c|c|c|c|c|c|c|c|c|c|c|}
\hline & 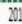 & & & & & 2018 & & & 20 & & & 2020 & \\
\hline & & & 3 & 4 & & & & a & & 3 & 4 & 2 & \\
\hline |hasixk:lezal & & & & & & & & & & & & & \\
\hline Incopopotion & & & & & & & & & & & & & \\
\hline 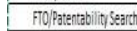 & & & & & & & & & & & & & \\
\hline Ppring & & & & & & & & & & & & & \\
\hline 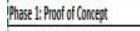 & & & & & & & & & & & & & \\
\hline Intibal frovopping & & & & & & & & & & & & & \\
\hline Scertificand Tethical & & & & & & & & & & & & & \\
\hline 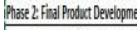 & & & & & & & & & & & & & \\
\hline Define Design nnutsiou & & & & & & & & & & & & & \\
\hline Finalize Denice Des \&n & & & & & & & & & & & & & \\
\hline 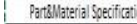 & & & & & & & & & & & & & \\
\hline 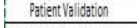 & & & & & & & & & & & & & 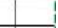 \\
\hline Phase ? Regulatary Appovel & & & & & & & & & & & & & \\
\hline 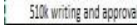 & & & & & & & & & & & & & \\
\hline Fot $60 p 00$ al & & & & & & & & & & & & & \\
\hline 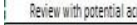 & & & & & & & & & & & & & \\
\hline 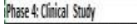 & & & & & & & & & & & & & \\
\hline 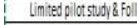 & & & & & & & & & & & & & \\
\hline Rerew with poternial aco & & & & & & & & & & & & & \\
\hline lagererandonized stuoy & & & & & & & & & & & & & \\
\hline Phase: : Vartiet tunch & & & & & & & & & & & & & \\
\hline Intita sale force hives & & & & & & & & & & & & & \\
\hline 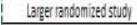 & & & & & & & & & & & & & \\
\hline Disstbust launh & & & & & & & & & & & & & \\
\hline Sal forcepouth & & & & & & & & & & & & & \\
\hline
\end{tabular}

\section{REGULATORY}

What is the projected device classification? (e.g. Class I, II, III)

Our projected device classification is Class 1I. The classification name of our device is powered muscle stimulator. The product codes for NMES devices and TENS devices are IPF and GZJ respectively.

\section{What is the regulatory pathway?}

Our device will likely undergo the $510(\mathrm{~K})$ submission. The premarket review will likely be performed by the office of device evaluation, division of neurological and physical medicine devices (physical medicine and neurotherapeutic devices branch).

\section{Are there existing predicates?}

Existing predicate devices in terms of indication and technology include Kneehab XP, Cymedica QB1 and Empi Phoenix. For the purposes of FDA's regulation of medical devices, we will demonstrate our device to be substantially equivalent in indications and design principles to predicate devices. In addition, we will collate and compile data included to be included into the regulatory submission to demonstrate substantial equivalence to the predicate devices. The intended use, design, materials and functional characteristics of our device and the predicate devices are substantially the same. Both our device and the predicate devices are for prescription use, portable, hand-held, and home healthcare environment devices.

\section{R\&D PLAN AND CLINICAL TRIALS}

\section{R\&D Plan}

\begin{tabular}{|l|l|}
\hline R\&D Milestones & Key R\&D Risks \\
\hline $\begin{array}{l}\text { First works-like } \\
\text { prototype that } \\
\text { performs safely and } \\
\text { effectively in } \\
\text { patients. }\end{array}$ & $\begin{array}{l}- \text { Finding the material that is } \\
\text { flexible and comfortable for the } \\
\text { skin. } \\
- \text { Ensuring the sensor system } \\
\text { can detect the accurate knee gesture. }\end{array}$ \\
\hline $\begin{array}{l}\text { Pre-production } \\
\text { model that performs } \\
\text { safely and } \\
\text { effectively in } \\
\text { patients. }\end{array}$ & $\begin{array}{l}- \text { Optimizing the functionality of the } \\
\text { system for use on a larger scale. - } \\
\text { Confirming the device can be } \\
\text { manufactured at a reasonable cost. }\end{array}$ \\
\hline $\begin{array}{l}\text { Market-ready model } \\
\text { that perform safely } \\
\text { and effectively in } \\
\text { humans. }\end{array}$ & $\begin{array}{l}- \text { Optimizing the functionality } \\
\text { of the system for use on a commercial } \\
\text { scale. } \\
- \\
\text { manufacturability of all device } \\
\text { components. }\end{array}$ \\
\hline
\end{tabular}

\section{Clinical Trial}

A premarket notification, or $510(\mathrm{k})$, is submitted to FDA before a manufacturer proposes to market a medical device. If FDA agrees the new device is substantially equivalent to a legally marketed device for which premarket approval is not required, we may market it immediately. FDA does not require clinical data in most $510(\mathrm{k}) \mathrm{s}$.

To demonstrate the safety, our device will be tested for electrical safety, electromagnetic compatibility, usability, biocompatibility, and risk management requirements. To demonstrate the safety, our device will be tested as per the following standards:

\begin{tabular}{|l|l|}
\hline $\begin{array}{l}\text { Technical } \\
\text { Standard }\end{array}$ & Description \\
\hline $\begin{array}{l}\text { IEC 60601- } \\
1\end{array}$ & $\begin{array}{l}\text { General requirements for basic safety and } \\
\text { essential performance. }\end{array}$ \\
\hline $\begin{array}{l}\text { IEC 60601- } \\
1-2\end{array}$ & $\begin{array}{l}\text { General requirements for basic safety and } \\
\text { essential performance- Collateral standard: } \\
\text { Electromagnetic compatibility requirements. }\end{array}$ \\
\hline $\begin{array}{l}\text { IEC 60601- } \\
2-10\end{array}$ & $\begin{array}{l}\text { Particular requirements for the basic safety } \\
\text { and essential performance of nerve and } \\
\text { muscle stimulator. }\end{array}$ \\
\hline $\begin{array}{l}\text { IEC 60601- } \\
1-11\end{array}$ & $\begin{array}{l}\text { General requirements for basic safety and } \\
\text { essential performance- Collateral standard: } \\
\text { Requirements for medical electrical } \\
\text { equipment and medical electrical systems } \\
\text { used in the home healthcare environment. }\end{array}$ \\
\hline $\begin{array}{l}\text { IEC 60601- } \\
1-6\end{array}$ & $\begin{array}{l}\text { General requirements for basic safety and } \\
\text { essential performance- Collateral standard: } \\
\text { Usability including IEC 62366: Application of } \\
\text { usability engineering to medical devices. }\end{array}$ \\
\hline
\end{tabular}




\section{International Journal of Engineering Applied Sciences and Technology, 2020 \\ Vol. 4, Issue 9, ISSN No. 2455-2143, Pages 14-25 \\ Published Online January 2020 in IJEAST (http://www.ijeast.com)}

\begin{tabular}{|l|l|}
\hline IEC 62366 & $\begin{array}{l}\text { Application of usability engineering to } \\
\text { medical devices. }\end{array}$ \\
\hline $\begin{array}{l}\text { ISO 10993- } \\
1\end{array}$ & $\begin{array}{l}\text { Evaluation and testing within a risk } \\
\text { management process. }\end{array}$ \\
\hline $\begin{array}{l}\text { ISO 10993- } \\
5\end{array}$ & Tests for in vitro cytotoxicity. \\
\hline $\begin{array}{l}\text { ISO 10993- } \\
10\end{array}$ & Tests for irritation and skin sensitization \\
\hline ISO 14971 & $\begin{array}{l}\text { Application of risk management to medical } \\
\text { devices. }\end{array}$ \\
\hline
\end{tabular}

In addition, we will also demonstrate our device effectiveness and performance substantial equivalency compared to the predicate devices Kneehab XP, Cymedica QB1 and Empi Phoenix using the following FDA guidance documents: FDA Final Guidance Document for Powered Muscle Stimulator 510(k), June 9, 1999 as well as FDA Draft Guidance Document, Class II special controls guidance document: Transcutaneous electrical nerve stimulator for pain relief, April 5, 2010.

\section{REIMBURSEMENT}

Currently, the physical therapy is covered by the most insurance companies with a cap before and after surgery. Insurance coverage on physical therapy varies. Medicare limits how much outpatient therapy it will cover annually, although coverage is allowed for medically necessary therapy over the cap. In 2016, Medicare will cover up to $\$ 1,960$ worth of physical therapy (PT) and speech-language pathology (SLP) combined.

In article The Effects of the Number and Frequency of Physical Therapy Treatments on outcomes of treatment in Patients with Anterior Cruciate Ligament Reconstruction, the Mark S. and Kecia E. concluded that by following a structured physical therapy program postoperatively, it is possible for patients to achieve a successful outcome with a limited number of routine physical therapy visits. (Carlo, 1997)

If we can prove that our innovation can help reduce cost of therapy by reducing the number of therapy visits needed, we have a good chance to have it covered by insurance companies. The key to achieve cost reduction is patient compliance.

Wearable device that offers objective monitoring and feedback on patients condition was seen as an alternative way to provide supervision when away from a clinical setting to "reinforce what you learn and helping you to remember how to do it" and hence, maintain achieved benefits without slip back into bad habits.(Papi, 2015)

\section{CONCLUSION}

\section{BUSINESS MODEL}

Based on our analysis above, the value we offer through our innovation is a more cost effective treatment for ACL patients who need to go through long time of physical therapy. This can be achieved through improved patient compliance at home thus reducing cost of access to therapist.

One monetization model is to charge on the use of device. The device will offer mobility enhancer function as well as feedback to patients on their exercise and condition to help enhance prescribed rehab at home. Related data will be updated into cloud. Authorized access to patient data will be granted to patients and their PT.

If possible, ideally, we can run business on eco-friendly model, renting device out to patients and charge on a daily basis. That requires certain level of customization to be realized in final product in product design phase.

\section{SALES AND MARKETING PLAN}

1. Target customers: patients had ACL reconstruction surgery, who need to go through 6-9 months of rehab after surgery

2. Target stakeholders: surgeon and insurance companies.

3. Sales and marketing plan:

Engage key decision maker: insurance companies are the key in sales and marketing. If we can prove our innovation would help reduce the cost of therapy by reducing the number of PT visits needed without compromising patient outcome, we have a good chance of having the payment covered by insurance companies.

Through engaging insurance companies, we aim to have our product to be adopted as part of standard treatment of therapy. Stakeholder analysis has shown that both therapists and patients, the other two key decision makers, would welcome such change.

- Run a lean operation model: rental + mail-to-order to bridge patients' access to service and product. Rental model allows cost reduction compared with purchase model. Thus, it encourages payer to accept the product.

- Online + Offline service: each patient will have an online account in addition to the physical device. Patients and therapists can easily order/return device and access data and feedback on patient knee activity.

\section{FUNDING AND FINANCIALS}

\section{Timeline}

a. R\&D and Product development: 12 months

b. Clinical trial: 12-30 months

c. Regulatory filing and FDA approval: 30-36 months

d. Product manufacture and launch preparation: $36-48$ months

Funding requirement:

a. Cost estimate: 
- R\&D: \$35k each year

- Clinical trial: total $\$ 0.4$ million o Patient recruitment: $\$ 400 * 200=\$ 80$ K o Material cost: $\$ 200 * 500=\$ 0.1$ million

O Physician and therapist compensation: $\$ 1000 * 100=\$ 0.1$ million

- FDA approval: total $\$ 40-55 \mathrm{k}$ o Attorney and consultancy cost: $\$ 10-15 \mathrm{k}$ o Filing cost in multiple countries: \$30-40k - Marketing cost: \$100-300k each year after FDA approval $\bullet$ Manufacture cost:

○ \$400k set up cost o Cost of goods Sold:

\begin{tabular}{|l|l|}
\hline \multicolumn{2}{|l|}{ Manufacture cost estimate (per unit) } \\
\hline $\begin{array}{l}\text { Polymer based silicone or PDMS for } \\
\text { knee sleeve }\end{array}$ & $\begin{array}{l}\$ 1 \text { each, \$3 in } \\
\text { total }\end{array}$ \\
\hline 3 flexible silicone sensor & $\$ 2$ \\
\hline Wireless sync controller & $\$ 1$ \\
\hline Memory chip & $\$ 5$ \\
\hline LCD display, lights, keyboard pad, etc. & $\$ 15$ \\
\hline Assembly, storage and logistic & \\
\hline \multicolumn{1}{|c|}{ account setting-up and } & $\$ 1$ \\
\hline $\begin{array}{l}\text { Online } \\
\text { maintenance }\end{array}$ & $\$ 3$ \\
\hline Other material & About \$33 \\
\hline Total &
\end{tabular}

About 6000 units of device needed in the first year of manufacture, 44,000 needed in each of the next two years

\section{- Hiring Plan and cost:}

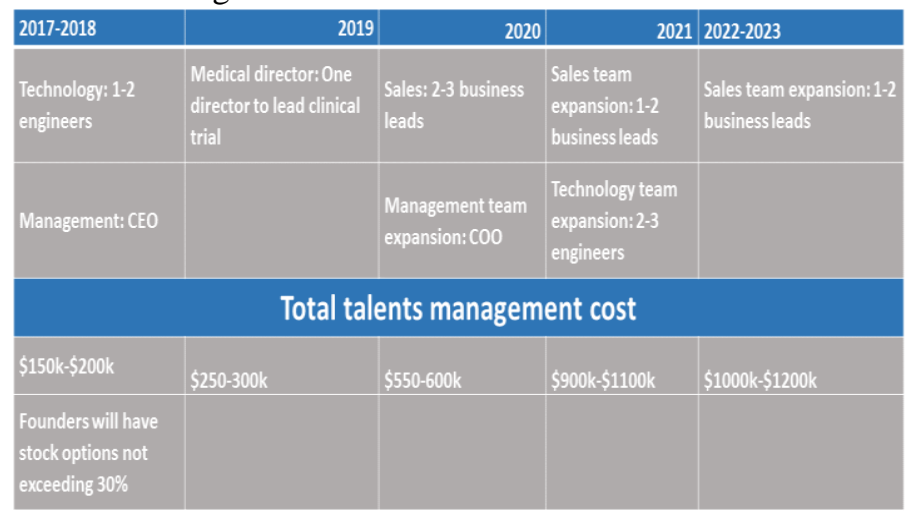

\section{b. Revenue projection:}

Total addressable market from device rental is estimated as below

$+100 \mathrm{k}$ patients $* \$ 3$ per day $* 180$ days $=\$ 54$ million each year We aim to reach $6 \%$ of market share the first year, $15 \%$ the second year and $50 \%$ in the third year after product launch.
Under current estimation, it costs \$540 US dollars for each patient to use our product for 6 month about $27.5 \%$ of the total PT allowance of Medicare each year. The relatively low cost will increase the chance of insurance companies covering this treatment device.

\section{c. Funding needs (in thousand US dollars):}

\begin{tabular}{|c|c|c|c|c|c|c|c|}
\hline Year & 2017 & 2018 & 2019 & 2020 & 2021 & 2022 & 2023 \\
\hline$R \& D$ cost & -35 & -35 & -35 & -35 & -35 & -35 & -35 \\
\hline Clinical trial & 0 & -80 & -80 & 0 & 0 & 0 & 0 \\
\hline $\begin{array}{l}\text { FDA } \\
\text { Approval }\end{array}$ & 0 & 0 & 0 & -55 & 0 & 0 & 0 \\
\hline Marketing & 0 & 0 & 0 & 0 & -100 & -200 & -300 \\
\hline Manufacture & 0 & 0 & 0 & 0 & -238 & -1452 & -1452 \\
\hline $\begin{array}{l}\text { Talents } \\
\text { management }\end{array}$ & -200 & -200 & -300 & -500 & -800 & -1000 & -1000 \\
\hline Total cost & -285 & -485 & -485 & -340 & -1185 & -700 & -700 \\
\hline Revenue & & & & & 3240 & 10800 & 27000 \\
\hline Profit & -520 & -800 & -900 & -930 & 882 & 7413 & 23513 \\
\hline $\begin{array}{l}\text { Funding } \\
\text { needed }\end{array}$ & -520 & -800 & -900 & -930 & N/A & N/A & N/A \\
\hline Notes & 2017 & & & & $\begin{array}{l}\text { Product } \\
\text { launch } \\
\text { and } \\
\text { profitabilit } \\
\text { y starts }\end{array}$ & & $\begin{array}{l}\text { Recom } \\
\text { men } \\
\text { ded exit } \\
\text { point }\end{array}$ \\
\hline
\end{tabular}




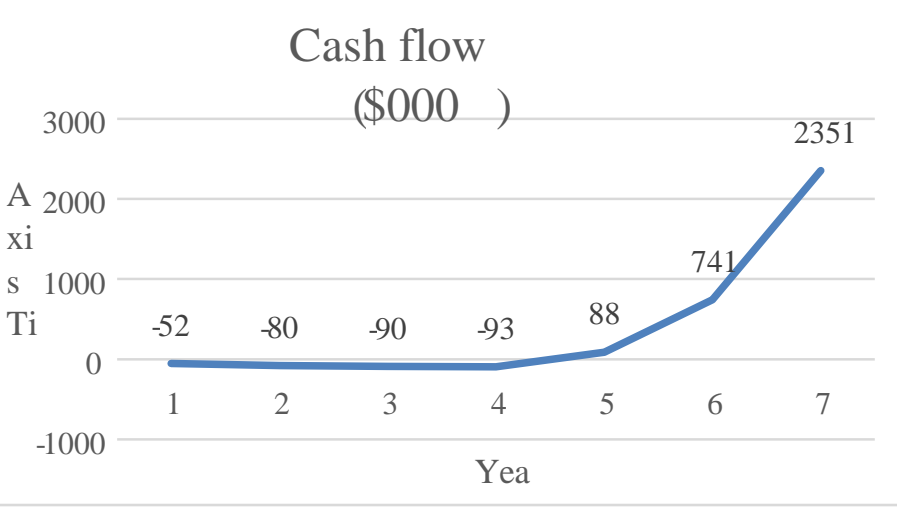

Fiure : Cash Flow from -2023

\section{d. Valuation at Exit:} Assumptions

- $\quad$ Investment Duration: 7 years (2017-2023)

- Stock options for founders: no more than $30 \%$

- $\quad$ Estimated profit in 2023: \$23.51million

- $\quad$ Required return: $10 \%$ each year

- Annual revenue increases 3\% each year after 2023

\begin{tabular}{|c|c|c|c|c|}
\hline Year & 2017 & 2018 & 2019 & 2020 \\
\hline Funding needed (PV) & $\$ 0.52$ MILION & $\$ 0.8$ MLLLION & $\$ 0.9$ MILLION & $\$ 0.93 \mathrm{MLLLON}$ \\
\hline Total|(PV) & & $\$ 2.44 \mathrm{MLL}$ & LLON & \\
\hline
\end{tabular}

\section{Valuation}

Present value of total investment at beginning of 2017 is $\$ 2.44$ MM.

The present value of total revenue from 2021-2033 at beginning of 2017 is $\$ 100.66 \mathrm{MM}$.

Assume investors have $70 \%$ shares of the company: $\$ 100.66 * 70 \%=\$ 70.46 \mathrm{MM}$

Under this very conservative set of assumptions, revenue from 2021-2023 already gives you $\left(\mathbf{7 0 . 4 6}^{*}\left(\mathbf{1 . 1}^{\wedge} \mathbf{7}\right) / \mathbf{2 . 4 4}\right)^{\wedge}(\mathbf{1} / \mathbf{7})-\mathbf{1}=$ $\mathbf{7 7 . 8 4 \%}$ rate of annualised return

\section{FUTURE PHASE}

Another monetization strategy is to utilize the data collected, of which we have ownership and sell analysis and dataset to insurance companies and other institutes.

As wearable equipment, the device enables data gathering by user authorization. Health and fitness related data gathered, over an extensive period of time (6-9 months), will help insurance companies differentiate customers and enable accurate pricing for life and healthcare. It will also help with claim processing based on how much compliance patients have performed during therapy.

This source of revenue will be enabled once we have accumulated a large pool of user data.

\section{ACKNOWLEDGEMENT}

This project is made possible with the support from the Singapore Stanford Biodesign program and hence the author would like to thank the program faculty for all their support and guidance.

\section{REFERENCE}

[1] A.Veale, n.d. Case Study: Active Elbow Brace. [Online]

[2] Available http://softroboticstoolkit.com/stretchsense/case-study [Accessed 2 November 2016].

[3] Anon., n.d. [Online]

[4] Available at: http://emedicine.medscape.com/article/1252414-overview

[5] Anon., n.d. [Online]

[6] Available at: http://orthosurg.ucsf.edu/patientcare/divisions/sportsmedicine/conditions/knee/anteriorcruciate-ligamentinjury-acl/

[7] Anthony Delitto, S. J. R. J. M. M. R. C. L. J. A. T. a. R. A. S., 1988 May. Electrical Stimulation Versus Voluntary Exercise in Strengtheing Thigh Musculature After Anterior Curciate Ligament Surgery. Phys Ther, Volume 68, pp. 660-663.

[8] Ben O'Brien, T. G. I. A. H. M. S. J. P. A. H. N. N. R. M. J. N., 2012-2016. Wearable motion capture sensors that measure stretch, pressure, bend, and shear. [Online] Available at: https://stretchsense.com [Accessed 2 November 2016].

[9] Carlo, M. \&. S. K. E., 1997. The Effects of the Number and Frequency of Physical Therapy Treatments on Selected Outcomes of Treatment in Patients with Anterior Cruciate Ligament Reconstruction.. J Ortho Sports Phys Ther, 26(6), pp. 332-339.

[10] Derek M. Hansen, C. S. S., n.d. Electrical Muscle Stimulation: Five reasons why you need to adopt this technology for your athletes now. [Online]

[11] Available at: https://simplifaster.com/articles/electricalmuscle-stimulation-five-reasons-need-adopttechnologyathletes-now/

[12] [Accessed 1 November 2016].

[13] Elmqvist LG, L. R. J. C. e. a., 1988. Does a torn anteriror cruciate ligament lead to change in the central nervous drive of the knee extensors. Eur J Appl Physiol Occup Physiol, Volume 58, pp. 203-7. 


\section{International Journal of Engineering Applied Sciences and Technology, 2020 \\ Vol. 4, Issue 9, ISSN No. 2455-2143, Pages 14-25 \\ Published Online January 2020 in IJEAST (http://www.ijeast.com)}

[14] Eric C. Hartman, L. G. B. T. S. A. J. D. A., 2015. Exercise device for use with electical stimulation and related methods. USA, Patent No. US9114255 B1.

[15] Eriksson E, H. T., 1979. Comparison of isometric muscle training and electrical stimulation supplementing isometric muscle training in the recovery after major knee ligament surgery.. AM J Sports Med, Volume 7, pp. 16971 .

[16] Feil S, N. J. M. C. P. H., 2011 June. The Effectiveness of Supplementing a Standard Rehabilitaiton Program with Super Imposed NeuroMuscular Electrical Stimulation After Anterior Cruciate Ligament Reconstruction. Prospective, Randomized, Single-Blind Study. Am J Sports Med, 39(6), pp. 1238-47.

[17] Fitzgerald GK, P. S. I. J., 2003. A modified neuromuscular electrical stimulation protocol for quadriceps strength training following anterior cruciate ligament reconstruction.. J Orthop Sports Phys Ther, Volume 33, pp. 492-501.

[18] Fucai Han, A. B. L. S. L. K., 2015 December. Increased Compliance With Supervised Rehabilitation Improves Functional Outcome and Return to Sport After Anterior Curciate Ligament Reconstruction in Recreational Athletes. Orthopaedic Journal of Sports, 3(no. 12 2325967115620770).

[19] Global, D., 2016. Empi Phoenix. [Online]

[20] Available at: http://www.djoglobal.com/content/empiphoenix [Accessed 4 November 2016].

[21] Karnad P, M. S., 2011 Nov 16. Physiotherapists' perceptions of patient adherence to home exercises in chronic musculoskeletal rehabilitation.. International Journal of Physiotherapy and Rehabilitation, 16 Nov.Issue Edition 1.

[22] Kirsten Jack, S. M. M. J. K. M. a. E. G., 2010 Jun. Barriers to treatment adherence in physiotherapy outpatient clinics: A systematic review. Man Ther, 15(32), pp. 220-228.

[23] Leonard T. buller, M. M. J. B. B. M. G. B. M. a. L. D. K., 2015. Trends in Anterior Curciate Ligament Reconstruction in the Unitied States. The Orthopaedic Journal of Sports Medicine.

[24] Lorentzon R, E. L. S. M. e. a., 1989. Thigh musculature in relation to chronic anterior curciate ligament tear: muscle size, morphology, and mechanical output before reconstruction.. Am J Sports Med, Volume 17, pp. 423-9.

[25] Louis Michael Crowe, C. M. M., 2005. Method and apparatus for electrical stimulation. USA, Patent No. US6944503 B2.

[26] Manske, r. C. D. P. a. B. L., 2012. Recent advances following anterior cruciate ligament reconstruction: rehabilitation perspectives.. Current reviews in musculoskeletal medicine, Volume 5.1, pp. 59-71.
[27] Matt Ball, C. O. X. B. D. S. a. A. P., 2016. Silicone Soft Sensor Platform. [Online] Available at: http://www.bendlabs.com/ [Accessed 2 November 2016].

[28] Neurotech, 2015. Muscle Rehabilitaiton \& Pain Management. [Online] Available at: http://www.neurotechgroup.com/us/products/kneehab-xp [Accessed 4 November 2016].

[29] Orthopedics, C., n.d. The QB1 Experience. [Online]

[30] Available at: https://www.cymedicaortho.com/qb1experience [Accessed 4 November 2016].

[31] P. Colombet, D. D. J.-C. P. R., 2010. Current concept of partial anterior cruciate ligament ruptures.

[32] Palmieri-Smith, R. M. ,. A. C. T. a. E. M. W., 2008. Maximizing quadriceps strength after ACL reconstruction. Clinic in sports medicine, Volume 27.3, pp. 405-424.

[33] Papi, E. B. A. \&. M. A. H., 2015. A knee monitoring device and the preferences of patients living with osteoarthritis: A qualitative study. BMJ Open, 5(9).

[34] Reportlinker, 2013-2019. Orthopedic Soft tissue Repair Market (Surgical Procedures ACL/PCL

[35] Reconstruction, Meniscla Repair, Rotator Cuff Repair, Hip Arthroscopy, Biceps Tenodesis and Shoulder

[36] Labrum Repair- Global Industry Analysis, Size, Share, Growth, Trends and Forecast. [Online]

[37] Available at: http://www.prnewswire.com/newsreleases/orthopedic-soft-tissue-repair-marketsurgicalprocedures---aclpcl-reconstruction-meniscalrepair-rotator-cuff-repair-hip-arthroscopy-bicepstenodesisand-shoulder-labrum-repair---global-industryanalysis-size-share- [Accessed 4 November 2016].

[38] Riann M. Palmieri-Smith, A. G. T. E. M. W., 2008. Maximizing Quadriceps Strength After ACL Reconstruction. Clin Sports Med, Volume 27, pp. 405424.

[39] Snyder-Mackler L, D. A. S. S. B. S., 1994 Oct. Use of electrical stimulation to enhance recovery of quadriceps femoris muscle force production in patients following anterior cruciate ligament reconstruction.. Phys Ther, Volume 74(10), pp. 901-7.

[40] Springs), C. h. (. M., 2012 May. Pre-Opreative Rehabilitation Program for Knee Arthroscopy, s.l.: s.n.

[41] Struan Coleman, C. D. E. G., 2014 . System and methods for treating or supporting human joints or a portion of the human body. USA, Patent No. US20140276298 A1.

[42] Struan Coleman, J. F.-B. C. D., 2014. Systems and methods for treating human joints. USA, Patent No. US8870798 B2.

[43] Theoderick Tam, M. J. F. F. A. A. M., 2016. Apparatus and method for range of motion tracking with integrated reporting. USA, Patent No. US20160220175 A1. 
[44] Timothy E. Hewett, K. R. F. B. J. H. G. D. M., 2010. Understanding and preventing ACL injuries: current biomedchanical and epidemiologic considerations. $N \mathrm{Am}$ J Sports Phys Ther.

[45] Wigerstad-Lossing I, G. G. J. T., 1988. Effects of electrical muscle stimulation combined with voluntary contractions after knee ligament surgery.. Med Sci Sports Exerc, Volume 20, pp. 93-9. 